\title{
A Dutch and an English spelling test for Dutch-English bilingual university students
}

\author{
Marc Brysbaert \& Heleen Vander Beken \\ Department of Experimental Psychology \\ Ghent University
}

\author{
Address: $\quad$ Marc Brysbaert \\ Department of Experimental Psychology \\ Ghent University \\ Henri Dunantlaan 2 \\ B-9000 Gent \\ Belgium \\ Tel. +3292649425 \\ Fax. +3292646496 \\ E-mal: marc.brysbaert@ugent.be
}




\section{Abstract}

Individual differences are becoming important in language research. Central variables are vocabulary size, working memory capacity, and language exposure. Another variable of interest is spelling proficiency. The present text discusses the creation and assessment of a Dutch an English spelling test for undergraduate university students. 
Individual differences are becoming important in language research. For instance, it has been reported that the word frequency effect is larger in participants with a small vocabulary size than in participants with a large vocabulary size (Brysbaert, Lagrou, \& Stevens, 2017; Diependaele, Lemhöfer, $\&$ Brysbaert, 2013), arguably as a result of differences in language exposure. People with much exposure to language have a larger vocabulary and a smaller frequency effect than people with less exposure.

Exposure to language is sometimes measured directly with the Author Recognition Test. Participants are asked to indicate which names of book authors they know. Foils are included to correct for response bias. Scores on the test correlate with vocabulary size and various other measures of language processing. They also correlate with measures of empathy and theory of mind. Hintz and Brysbaert (2019) developed a Dutch Author Recognition Test. Their article includes a discussion of the test and references to American resources.

A third variable regularly examined is working memory capacity, although the results here are less strong. Dixon, LeFevre, and Twilley (1988), for instance, reported that vocabulary size correlated significantly with reading comprehension, making inferences while reading, and reading rate (standard regression coefficients of $.3-.4$ in multiple regression analysis), whereas the effects of working memory capacity were lower (standard regression coefficients of .2) and different tests predicted different reading aspects. Similarly, Waters and Caplan (1996) reported that vocabulary size explained $47 \%$ of the variance in reading comprehension, whereas the best working memory measure added an extra 13\%. A comparable result was reported by Cain, Oakhill, and Bryant (2004) with 8-11 year-old children. Vocabulary related variables accounted for $40 \%$ of the variance in reading comprehension, and working memory capacity explained an extra $6 \%$ of the variance.

Andrews and colleagues investigated the importance of a fourth variable: spelling proficiency (see also Burt \& Jared, 2016). Andrews and Hersch (2010) argued that there should be a strong correlation between spelling skill and reading skill, partly because spelling proficiency depends on exposure to written language, but also because spelling proficiency is an indication of how detailed the reader's lexical representations are. According to the authors, readers with detailed lexical representations have an advantage in reading compared to readers with less precise lexical representations. Andrews and Hersch (2010) correlated reading comprehension with vocabulary size and spelling precision. The correlations were respectively .53 and .47 (a working memory measure correlated .43). The correlation between vocabulary size and spelling proficiency was .5. Andrews and Hersch (2010) also provided evidence that highly proficient spellers process visual words differently than less proficient spellers. In a later study, Andrews and Lo (2013) reported that there was an interesting difference in visual word processing between participants with higher spelling than vocabulary abilities (orthographic profile) and participants with lower spelling than vocabulary abilities (semantic profile). In a further extension, Veldre and Andrews $(2014,2015)$ reported that participants with good spelling skills (and good vocabulary) extract more information from the parafoveal word in reading. The parafoveal word is the word to the right of the word currently fixated; that is, the word going to be processed next.

Andrews and Hersch (2010) developed two spelling tests. The first was a spelling dictation test and described as follows: "This test consisted of 20 words selected from items listed by Burt and Tate (2002) as having been correctly spelled by between $30 \%$ and $90 \%$ of their samples of Australian first- 
year university students. Each word was read aloud by the experimenter and included in a sentence to clarify ambiguities. The score for the test was the number of correctly spelled words. The testretest reliability coefficient of .90 indicates very high temporal stability."

The second test was a spelling recognition test, described as follows: "This was assessed using a list of 88 items, half correctly spelled and half misspelled. Misspellings changed one to three letters of the word and often preserved the pronunciation of the base word (e.g., addmission, seperate). Items were printed in columns on an A4 sheet, and participants were instructed to circle items they thought were incorrectly spelled. The recognition test score was the number of correctly classified items, both hits and correct rejections. Again, test-retest reliability was very high (.93)."

The correlation between the spelling dictation task and the spelling recognition task was .7. In two studies, the spelling dictation task correlated slightly more with reading comprehension than the spelling recognition task. As a result, we decided to develop spelling dictation tasks. Because Andrews and colleagues did not list the words used in het spelling tasks, we decided to develop a new English test, specifically geared towards our student population (Dutch-English bilingual university undergraduates), in addition to the Dutch spelling dictation test.

\section{The Dutch spelling dictation test}

The initial pool of stimuli for the Dutch spelling dictation test consisted of 92 words mentioned on various websites as 'tricky to spell'. For each word we composed a sentence to be read aloud with the word, but pilot testing indicated that this made the test too long and, therefore, that element of Andrews and Hersch's (2010) procedure was dropped.

The test was administered to 199 participants (see Vander Beken \& Brysbaert, 2018, for more information). ${ }^{1}$ Twenty-two words were spelled correctly by more than $95 \%$ of the participants. They were deleted from further analysis, as they do not allow us to differentiate between participants. An exploratory factor analysis (algorithm fa.parallel() from the R package 'psych'; Revelle, 2019; Sakaluk \& Short, 2017) on the remaining 70 items indicated a diffuse pattern. When the dependent variable was assumed to be continuous, five factors were proposed. When the analysis was based on polychoric correlations (as it should be given a binary dependent variable; Starkweather, 2014), the proposed number of factors was 68 .

To select the 35 best items, the loadings on a single factor model were used, together with the overall correctness scores. Table 1 lists the selected words. Average percentage correct of the selected stimuli is $73 \%$ (SD across items $=20$ ), compared to $M=78 \%$ (SD across items $=22$ ) for the full list. The reliability of the test, as measured with the intraclass correlation (ICC2k), is .82. The minimum split-half reliability is .76. This is acceptable, but there seems to be room for improvement (compare the data on the English spelling test below). A particular challenge is to find more good words that have reasonably high but not too high error rates.

\footnotetext{
${ }^{1}$ We also thank Evelyne Lagrou for her help.
} 
Table 1: Selected items for the Dutch spelling test. The second row indicates percentage correct in the group of Dutch-English bilingual undergraduate students tested. The third row lists the loadings on a one-factor model (based on polychoric correlations).

\begin{tabular}{|l|r|r|}
\hline Word & \% Correct & Factor load \\
\hline misleidend & 0.95 & 0.63 \\
\hline stiekem & 0.95 & 0.50 \\
\hline onbevreesd & 0.94 & 0.40 \\
\hline februari & 0.93 & 0.67 \\
\hline spaghetti & 0.93 & 0.46 \\
\hline madeliefje & 0.91 & 0.68 \\
\hline litteken & 0.91 & 0.47 \\
\hline afkickcentrum & 0.90 & 0.51 \\
\hline beschouwelijk & 0.89 & 0.50 \\
\hline yoghurt & 0.88 & 0.55 \\
\hline leidraad & 0.87 & 0.64 \\
\hline papegaai & 0.86 & 0.59 \\
\hline porselein & 0.84 & 0.58 \\
\hline pyjama & 0.83 & 0.40 \\
\hline hygiëne & 0.81 & 0.55 \\
\hline authentiek & 0.81 & 0.52 \\
\hline discipline & 0.80 & 0.56 \\
\hline patiënt & 0.79 & 0.64 \\
\hline cocaïnemaffia & 0.76 & 0.63 \\
\hline chagrijnig & 0.76 & 0.57 \\
\hline excentriek & 0.75 & 0.50 \\
\hline ingrediëntenlijst & 0.74 & 0.68 \\
\hline geïnteresseerd & 0.72 & 0.74 \\
\hline geliefkoosd & 0.71 & 0.70 \\
\hline geïrriteerd & 0.69 & 0.54 \\
\hline blindedarmontsteking & 0.69 & 0.49 \\
\hline achterwege laten & 0.64 & 0.60 \\
\hline calorieën & 0.56 & 0.51 \\
\hline bulldozer & 0.55 & 0.41 \\
\hline kannibaal & 0.46 & 0.44 \\
\hline slimmeriken & 0.45 & 0.40 \\
\hline geëlektrocuteerd & 0.42 & 0.45 \\
\hline versjouwen & 0.37 & 0.36 \\
\hline eczeem & 0.32 \\
\hline heden ten dage & 0.43 \\
\hline & & \\
\hline
\end{tabular}




\section{The English spelling dictation test}

For the English spelling dictation test we initially selected 92 words flagged on a several internet sites as 'tricky'. Because of time constraints, however, some participant groups did not get the final 12 words, leaving us with complete data for 80 words only. As for the Dutch spelling test, we made sentences in which the words were used, but in the end decided not to use them.

The test was administered to 198 participants (see Vander Beken \& Brysbaert, 2018, for more information). An exploratory factor analysis (algorithm fa.parallel() from the R package 'psych'; Revelle, 2019) suggested that the best solution included three correlated factors, when the dependent variable was assumed to be continuous. ${ }^{2}$ The first factor accounted for $12 \%$ of the variance, the other two for $3 \%$ of the variance each. There were five words loading more than .3 on factor two (in decreasing order of loadings): tyranny, rhythm, acquaintance, jewelry, and grateful. The factor correlated -.43 with the first factor. The five words loading more than .3 on factor three were (with decreasing loads): accidentally, incidentally, occasionally, honorary, and pronunciation. This factor also correlated negatively with factor one $(r=-.54)$. Several of these 10 words had low scores (less than $10 \%$ correct).

Because we prefer our scale to be unidimensional, we discarded the words with loadings on factors 2 and 3. We further discarded a few homophonic words (e.g., weather-whether), which are ambiguous if not read in a sentence, and words with a difference in spelling between American and British English (e.g., glamorous). We further pruned the words with equivalent spelling scores and words that did not load 3 on factor 1, until we had a final list of 30 words, shown in Table 2. Average score on the list was $58 \%$ (SD across items $=17$ ), against $M=50 \%$ (SD across items $=26$ ) for the complete list, indicating that in particular the words with low scores did not add much to the assessment. The reliability of the test, as measured with the intraclass correlation ICC $2 k$, is .88. The minimum split-half reliability is .85 , in line with the fact that the test measures a single factor.

\footnotetext{
${ }^{2}$ The solution with cor = "poly" proposed as many factors as variables. An analysis with three factors accounted for $35 \%$ of the variance and returned the same words as outliers.
} 
Table 2: Selected items for the English spelling test. The second row indicates percentage correct in the group of Dutch-English bilingual undergraduate students we tested; the third row indicates the loading on a single-factor model (polychoric correlations).

\begin{tabular}{|c|c|c|}
\hline Word & \% Correct & Factor load \\
\hline experience & 0.92 & 0.66 \\
\hline finally & 0.83 & 0.68 \\
\hline familiar & 0.79 & 0.58 \\
\hline religious & 0.77 & 0.59 \\
\hline miniature & 0.75 & 0.58 \\
\hline knowledge & 0.74 & 0.76 \\
\hline equipment & 0.72 & 0.50 \\
\hline completely & 0.71 & 0.66 \\
\hline politician & 0.70 & 0.64 \\
\hline achieve & 0.68 & 0.57 \\
\hline category & 0.66 & 0.55 \\
\hline ignorance & 0.65 & 0.57 \\
\hline library & 0.63 & 0.76 \\
\hline happened & 0.63 & 0.69 \\
\hline changeable & 0.62 & 0.57 \\
\hline exceed & 0.61 & 0.66 \\
\hline surprise & 0.56 & 0.55 \\
\hline receive & 0.52 & 0.44 \\
\hline acceptable & 0.51 & 0.57 \\
\hline persistent & 0.50 & 0.46 \\
\hline business & 0.49 & 0.64 \\
\hline column & 0.48 & 0.69 \\
\hline government & 0.46 & 0.44 \\
\hline appearance & 0.44 & 0.74 \\
\hline maintenance & 0.44 & 0.65 \\
\hline immediately & 0.43 & 0.71 \\
\hline unfortunately & 0.42 & 0.76 \\
\hline height & 0.33 & 0.41 \\
\hline preferred & 0.22 & 0.69 \\
\hline guarantee & 0.20 & 0.65 \\
\hline
\end{tabular}

\section{Conclusions}

This report presents the efforts we made to create a Dutch and an English spelling dictation test, to be used with Dutch-English bilingual university undergraduates. The English test looks good (on average $58 \%$ correct, reliability estimated on the basis of internal consistency $>.85$ ). The Dutch test is acceptable (on average $73 \%$ correct, reliability estimated on the basis of internal consistency $>.76$, despite having 5 items more), but there is room for improvement. In Vander Beken and Brysbaert (2018), the correlation between the Dutch and the English spelling tests was .61 (based on the full tests). The correlation between the English spelling test and an English vocabulary test was .5 (similar to what Andrews \& Hersch (2010) reported). The correlations between the Dutch spelling test and 
two Dutch vocabulary tests were .3 , but this was partly due to the lower reliabilities of the Dutch vocabulary tests used (see the correlations corrected for reliability). Still, the lower correlations are in line with the observation that further improvements for the Dutch test seem possible. ${ }^{3}$

\section{References}

Andrews, S., \& Hersch, J. (2010). Lexical precision in skilled readers: Individual differences in masked neighbor priming. Journal of Experimental Psychology: General, 139(2), 299-318.

Andrews, S. and Lo, S., 2013. Is morphological priming stronger for transparent than opaque words? It depends on individual differences in spelling and vocabulary. Journal of Memory and Language, 68(3), pp.279-296.

Brysbaert, M., Lagrou, E., \& Stevens, M. (2017). Visual word recognition in a second language: A test of the lexical entrenchment hypothesis with lexical decision times. Bilingualism: Language and Cognition, 20, 530-548.

Burt, J. S., \& Jared, D. (2016). The role of lexical expertise in reading homophones. The Quarterly Journal of Experimental Psychology, 69(7), 1302-1321.

Cain, K., Oakhill, J., \& Bryant, P. (2004). Children's reading comprehension ability: Concurrent prediction by working memory, verbal ability, and component skills. Journal of Educational Psychology, 96(1), 31-42.

Diependaele, K., Lemhöfer, K., \& Brysbaert, M. (2013). The word frequency effect in first and second language word recognition: A lexical entrenchment account. The Quarterly Journal of Experimental Psychology, 66,843-863.

Dixon, P., LeFevre, J. A., \& Twilley, L. C. (1988). Word knowledge and working memory as predictors of reading skill. Journal of Educational Psychology, 80(4), 465-472.

Hintz, F., \& Brysbaert, M. (2019, June 10). Dutch Author Recognition Test. https://doi.org/10.31234/osf.io/qapmx

Revelle, W. (2019, June 1). How To: Use the psych package for Factor Analysis and data reduction. http://personality-project.org/r/psych/HowTo/factor.pdf.

\footnotetext{
${ }^{3}$ Extra words than can be considered are: abonnee, adellijke, adequaat, allesbehalve, almanak, antiquair, apekool, applaudisseren, asymmetrisch, babyboom, barbecue, begroeiing, bespioneren, billijken, blocnote, bonafide, brousse, caissière, cappuccino, comité, conciërge, consequent, contra-expert, crèche, dichtstbijzijnd, dyslexie, euthanasie, ex aequo, excellentie, faillissement, faliekant, fascinerend, fauteuil, fetisj, feuilleton, filet, financieel, financieren, gebakkelei, gediskwalificeerd, gepermitteerd, gewelddadig, gezamenlijk, gynaecoloog, halsoverkop, halsstarrig, hasjiesj, idyllisch, impresario, kippenragout, kotelet, labyrint, laconiek, luxueus, maneschijn, mecenas, naïviteit, nochtans, nota bene, omelet, opticien, overzeese, panorama, perplex, portefeuille, pro forma, professor, quasi, quiz, razzia, recensie, regisseren, represaille, rigoureus, satelliet, scenario, seksualiteit, sensibilisering, silhouet, sowieso, stagiair, stikkapot, successie, synthetisch, tatoeëren, ter zake, uittreksel, vergalopperen, verrukkelijk, vleierig, weifelen
} 
Sakaluk, J. K., \& Short, S. D. (2017). A methodological review of exploratory factor analysis in sexuality research: Used practices, best practices, and data analysis resources. The Journal of Sex Research, 54(1), 1-9.

Starkweather, J. (2014, September). Factor Analysis with Binary items: A quick review with examples. https://it.unt.edu/sites/default/files/binaryfa I ids sep2014 0.pdf

Veldre, A. and Andrews, S., 2014. Lexical quality and eye movements: Individual differences in the perceptual span of skilled adult readers. The Quarterly Journal of Experimental Psychology, 67(4), pp.703-727.

Veldre, A., \& Andrews, S. (2015). Parafoveal preview benefit is modulated by the precision of skilled readers' lexical representations. Journal of Experimental Psychology: Human Perception and Performance, 41(1), 219-232.

Waters, G. S., \& Caplan, D. (1996). The measurement of verbal working memory capacity and its relation to reading comprehension. The Quarterly Journal of Experimental Psychology Section A, 49(1), 51-79. 